\title{
An Endodontic Sealer Induces a Pathological Condition when Associated with Persistent Tissue Toxicity and Presence of Myofibroblasts
}

\author{
Allan Fernando GIOVANINI ${ }^{1}$ \\ Denise Piotto LEONARDI ${ }^{1}$ \\ Flares BARATTO-FILHO ${ }^{1,2}$ \\ Paola Cristine VALENÇA ${ }^{1}$ \\ Ricardo César MORESCA ${ }^{1}$ \\ Alexandre $\mathrm{MORO}^{1}$ \\ Celso Alfredo SCHRAMM ${ }^{1}$
}

${ }^{1}$ Masters Program in Clinical Dentistry, Positivo University, Curitiba, PR, Brazil
${ }^{2}$ Univille - University of Joinville, Joinville, SC, Brazil

\begin{abstract}
The aims of this study were to evaluate the ratio between inflammatory reactions induced by four endodontic sealers and the occurrence of fibrosis and the number of myofibroblasts with positivity to $\alpha$-smooth-actin muscle ( $\alpha$-SMA). Polyethylene tubes were filled with a root canal sealer (Endofill, AH Plus, Acroseal and Epiphany) and inserted into 4 site at the dorsal region of 24 Wistar rats; 2 empty tubes (control) were grafted in 6 rats. After 7, 21, and 45 days, 8 animals were euthanized, providing 6 specimens per test group and 2 specimens from the control group. The fragments were subjected to histological processing and immunohistochemical analysis for anti $\alpha$-SMA protein. All specimens, except those from the control group, presented severe inflammatory reaction on the $7^{\text {th }}$ postoperative day, which also coincided with a large number of myofibroblasts. On the $21^{\text {st }}$ and $45^{\text {th }}$ days post-surgery, the inflammatory reaction induced by Endofill, AH Plus and Acroseal decreased significantly, which coincided with reduced presence of myofibroblasts and usual collagen deposition. In contrast, in the group filled with Epiphany, significant inflammatory cell infiltrate was present in all analyzed periods. The persistence of an inflammatory reaction induced by endodontic sealer may also induce the development of fibrosis in combination with presence of myofibroblasts.
\end{abstract}

Key Words: endodontic sealers, fibrosis, biocompatibility, myofibroblasts.

\section{INTRODUCTION}

In the endodontic practice, several types of sealer have been used to fill and seal the root canals $(1,2)$. Although these materials are manufactured to be used only within the root canal, they commonly extrude through the apical constriction (3). The contact of sealers with living tissue produces interactions with the complex biologic systems around where it occurs, resulting in a biologic response represented by the immune reaction.

Since there are no inert materials in dentistry (4) to minimize the toxic reactions to tissues, endodontic sealers are based on various formulations according to their main component (e.g., sealers based on zinc-oxide and eugenol, epoxy resin, methacrylate and calcium hydroxide), and these different formulations may produce different results in terms of toxicity, affecting the inflammatory response and tissue repair $(5,6)$.

During a usual repair and/or reconstitution of connective tissue, fibroblasts migrate into the wound, where they produce and remodel extracellular matrix, resulting in wound closure. These events commonly are mediated by a specialized form of fibroblasts, denominated myofibroblasts (7).

The myofibroblasts are terminally differentiated cells that express $\alpha$-smooth-actin muscle ( $\alpha$-SMA) filaments and share a hybrid phenotype between 
fibroblasts and muscle cells (8). After differentiation, these cells participate in wound healing by promoting the contraction necessary to restore homeostasis in damaged tissue, closing the repair process (9). The persistence of or changes in the life cycle of myofibroblasts is a hallmark of fibrotic lesions (10) similar to pathological fibro-proliferative conditions, such as scleroderma, kidney and lung fibrosis or myelofibrosis in bone.

Since inflammatory cytokines, especially interleukins and growth factors, are the main inducers of $\alpha$-SMA phenotype development and collagen synthesis and deposition $(7,11)$, it was hypothesized that the immune reactions induced by endodontic sealers could also contribute to pathological fibrosis. Thus, the aim of this study was to analyze the correlation between tissue toxicity developed by four endodontic sealers (Endofill, AH Plus, Acroseal and Epiphany) and the presence of fibrosis and myofibroblasts.

\section{MATERIAL AND METHODS}

Twenty-four 60-70-day old Wistar rats (Rattus novergicus) weighing 250-280 $\mathrm{g}$ and with no history of disease were used following a protocol approved by the Animal Care and Use Committee of Positivo University, Brazil (Protocol\#144/2008). The animals were kept in a room with controlled temperature (approximately $22^{\circ} \mathrm{C}$ ) and maintained under a $12 \mathrm{~h}$ light-dark cycle.

Before surgery, the animals were anesthetized with $8 \times 10^{-3} \mathrm{~mL} / \mathrm{g}$ of ketamine hydrochloride and $4 \times 10^{-3} \mathrm{~mL} / \mathrm{g}$ of $2 \%$ xylazine hydrochloride (Virbac do Brasil Indústria e Comércio Ltda., São Paulo, SP, Brazil). Dorsal shaving was performed and the area was disinfected using an iodine-polyvinylpyrrolidone (PVPI) solution.

In the experimental group, four $17 \mathrm{~mm}$-long incisions were performed on the dorsal region of each animal. The incisions were arranged in quadrants, equidistant from the center of the dorsum. Two incisions were made on the scapular region (one on the right side and the other on the left side - positions I and II, respectively) and the other 2 incisions were created on the pelvic region (one on the right side and the other on the left side - positions III and IV, respectively).

Polyethylene tubes $(10 \mathrm{~mm}$ long and $0.8 \mathrm{~mm}$ internal diameter) were autoclaved, had one of the ends closed and were filled with the following sealers, prepared according to the manufacturers' instructions: Group I - Endofill (Dentsply Ind. e Com. Ltda.,
Petrópolis, RJ, Brazil); Group II - AH Plus (Dentsply DeTrey, Konstanz, Germany); Group III - Acroseal (Septodont Brasil Ltda., Tamboré, SP, Brazil); and Group IV - Epiphany (Sybron Endo, Orange, CA, USA). The tubes containing the sealers were inserted into subcutaneous spaces created by blunt dissection. The tubes were grafted into the surgical cavities, parallel to the incisions, with the open end pointing to the animal's tail. Two animals per period were used as control and received an empty tube in the subcutaneous tissue of the dorsal region. Tissues were repositioned and the incisions were sutured with 5-0 nylon silk.

All animals were euthanized at 7,21 and 45 days postoperatively ( 6 animals per period in the test groups) by brief exposure to a $\mathrm{CO}_{2}$ chamber until they ceased moving.

\section{Tissue Processing}

Tissue fragments from the areas that contained the tubes were carefully necropsied with a 2-cm safety margin, and all fragments were fixed in $10 \%$ buffered formalin for $24 \mathrm{~h}$. The specimens were washed in tap water, dehydrated, cleared and embedded in paraffin.

Serial $3-\mu \mathrm{m}$-thick sections perpendicular to the long axis of the tubes were cut with a microtome (RM2155; Leica Microsystems GmbH, Nussloch, Germany) and stained with hematoxylin-eosin and Masson's Trichrome to detect deposition of collagen fibers.

\section{Immunohistochemistry Processing}

Three-micrometer-thick serial sections of these specimens were deparaffinized and subjected to antigen retrieval in $10 \mathrm{mM}$ citrate solution ( $\mathrm{pH} \mathrm{6.0)}$ ) for $45 \mathrm{~min}$ in a double boiler at $95^{\circ} \mathrm{C}$. The slides containing the histological specimens were incubated overnight with the primary antibody anti- $\alpha$-SMA (clone 1A4; Dako, Glostrup, Denmark) with dilution factor 1:150. The labeled streptavidin biotin (LSAB plus; Dako) antibodybinding detection system was used to detect the primary antibodies, and the specimens were then submitted to a solution composed of 3,3' diaminobenzidine tetrachloride (Sigma, St. Louis, MO, USA) for $3 \mathrm{~min}$ to reveal the reaction, producing a brown precipitate at the antigen site. All specimens were counterstained with Harris hematoxylin. For each specimen, 3 slides were used for incubation with antibody. 


\section{Image and Statistical Analysis}

Images of histological and immunohistochemistry sections were captured with a digital camera coupled to a light microscope with $\times 200$ original magnification. Each digital image was collected and saved with $600 \mathrm{dpi}$ resolution, producing a virtual picture of $117 \times 80 \mathrm{~cm}$. Five histological fields were analyzed in each specimen.

The analysis of the presence of fibrous tissue and the number of inflammatory and $\alpha-\mathrm{SMA}^{+}$cells was performed using the software Image Tool 2.00 (University of Texas Health Science Center; San Antonio, TX, USA). The perimeters of histological fibrous tissue and total area were carefully traced, and the following areas were computed while the quantity of the inflammatory and $\alpha-\mathrm{SMA}^{+}$cells per total cells were counted and tagged. The data were counted manually, transformed in percentage and expressed in scores graded as negative if they were $<5 \%$. Positive staining for cell markers was graded as $+(5-20 \%),++(21-40 \%),+++$ $(41-60 \%)$ and $++++(>60 \%)$.

Each parameter was evaluated separately within the established periods. Data were analyzed using Moda, to verify possible similarities between the groups.

\section{RESULTS}

\section{Quantitative and Qualitative Analysis of the Inflammatory Infiltrate}

A brief description of the histological features among groups was performed, while the quantitative parameters of the inflammatory response were summarized and demonstrated in Table 1 and in Figure 1 , respectively.

Group I (Endofill) - On the $7^{\text {th }}$ postoperative day, the microscopic analysis revealed moderate inflammatory infiltrate, composed predominately of lymphocytes and plasma cells surrounding the polyethylene tubes and edematous areas. On the $21^{\text {st }}$ day, discrete mononuclear inflammatory infiltrate remained around the tube, although well organized granulation tissue was present. On the $45^{\text {th }}$ day post-surgery, discrete inflammatory infiltrate was detected focally surrounding the polyethylene tube. In addition, connective tissue exhibiting usual morphology was seen, while the discrete fibrosis areas were observed surrounding the entire tube.

Group II (AH Plus) - On the $7^{\text {th }}$ postoperative day, mononuclear inflammatory infiltration restricted to the tube aperture was identified. In addition, a loose irregular connective tissue was present on the fragment analyzed. On the $21^{\text {st }}$ and the $45^{\text {th }}$ days post-surgery, an organized and vascularized connective tissue was apparent, without significant inflammatory response $(<5 \%)$.

Group III (Acroseal) - On the $7^{\text {th }}$ and $21^{\text {st }}$ days post-surgery, the histological analysis revealed an evident granulation tissue. On the $7^{\text {th }}$ postoperative day, a remarkable amount of diffuse inflammation infiltrate on the vascularized tissue was evident. This inflammatory infiltrate was composed predominantly of lymphocytes, plasma cells and macrophages. Presence of this inflammatory tissue decreased gradually on the

Table 1. Moda of score of the main histological features in the five groups at the three experimental periods.

\begin{tabular}{|c|c|c|c|c|c|c|c|c|c|c|c|c|c|c|c|}
\hline \multirow{2}{*}{$\begin{array}{l}\text { Histological } \\
\text { features }\end{array}$} & \multicolumn{5}{|c|}{7 days } & \multicolumn{5}{|c|}{21 days } & \multicolumn{5}{|c|}{45 days } \\
\hline & GI & GII & GIII & GIV & GV & GI & GII & GIII & GIV & GV & GI & GII & GIII & GIV & GV \\
\hline Macrophages & ++ & ++ & ++ & ++ & - & + & ++ & ++ & +++ & - & - & - & - & +++ & - \\
\hline Lymphocytes & +++ & +++ & ++++ & ++++ & - & ++ & ++ & ++ & ++++ & - & - & - & + & +++ & - \\
\hline Plasma cells & +++ & +++ & ++++ & ++++ & - & ++ & ++ & ++ & ++++ & - & - & - & + & +++ & - \\
\hline $\begin{array}{l}\text { Foreign body } \\
\text { giant cells }\end{array}$ & - & - & - & - & - & - & - & - & - & - & - & - & - & - & - \\
\hline Necrosis & - & - & - & - & - & - & - & - & - & - & - & - & - & - & - \\
\hline $\begin{array}{l}\text { Fibrous } \\
\text { deposition }\end{array}$ & + & + & + & +++ & - & + & - & + & +++ & - & - & - & - & +++ & - \\
\hline$\alpha-\mathrm{SMA}^{+}$cells & ++ & ++ & ++ & + & - & ++ & + & + & ++++ & - & + & - & - & ++++ & - \\
\hline
\end{tabular}


$21^{\text {st }}$ and $45^{\text {th }}$ day of analysis. On the $45^{\text {th }}$ day postsurgery, few inflammatory cells were present, although a thin fibrous tissue layer was concentrated around the polyethylene tube.

Group IV (Epiphany) - The histological frame induced by Epiphany revealed the presence of a remarkable and diffuse inflammatory response in all time periods monitored. On the $7^{\text {th }}$ day post-surgery, the microscopy analysis of these specimens demonstrated both acute and mononuclear inflammatory infiltrate in the entire necropsied tissue. It was also observed a focus of necrosis, especially where there was intimate contact between the live tissue and sealer ( $4 / 6$ specimens). On the $21^{\text {st }}$ and $45^{\text {th }}$ days post-surgery, diffuse and predominately mononuclear inflammation (predominately plasma cells, lymphocytes and macrophages) was identified, and also a discrete number of giant cells were observed.

Group V (Control) - Isolated inflammatory
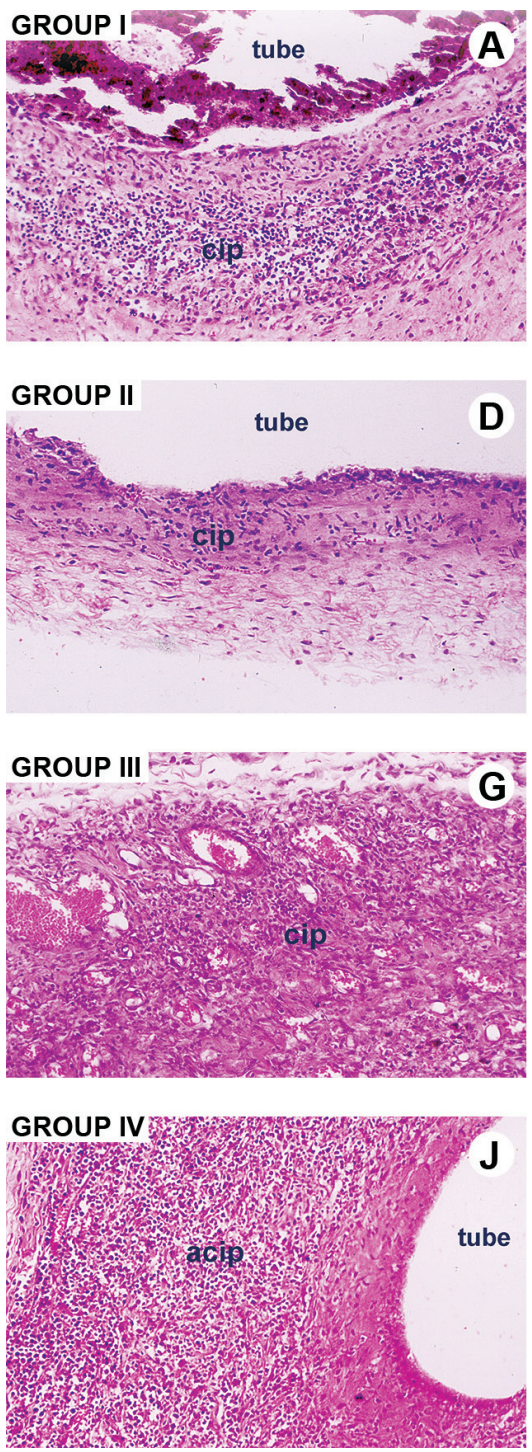
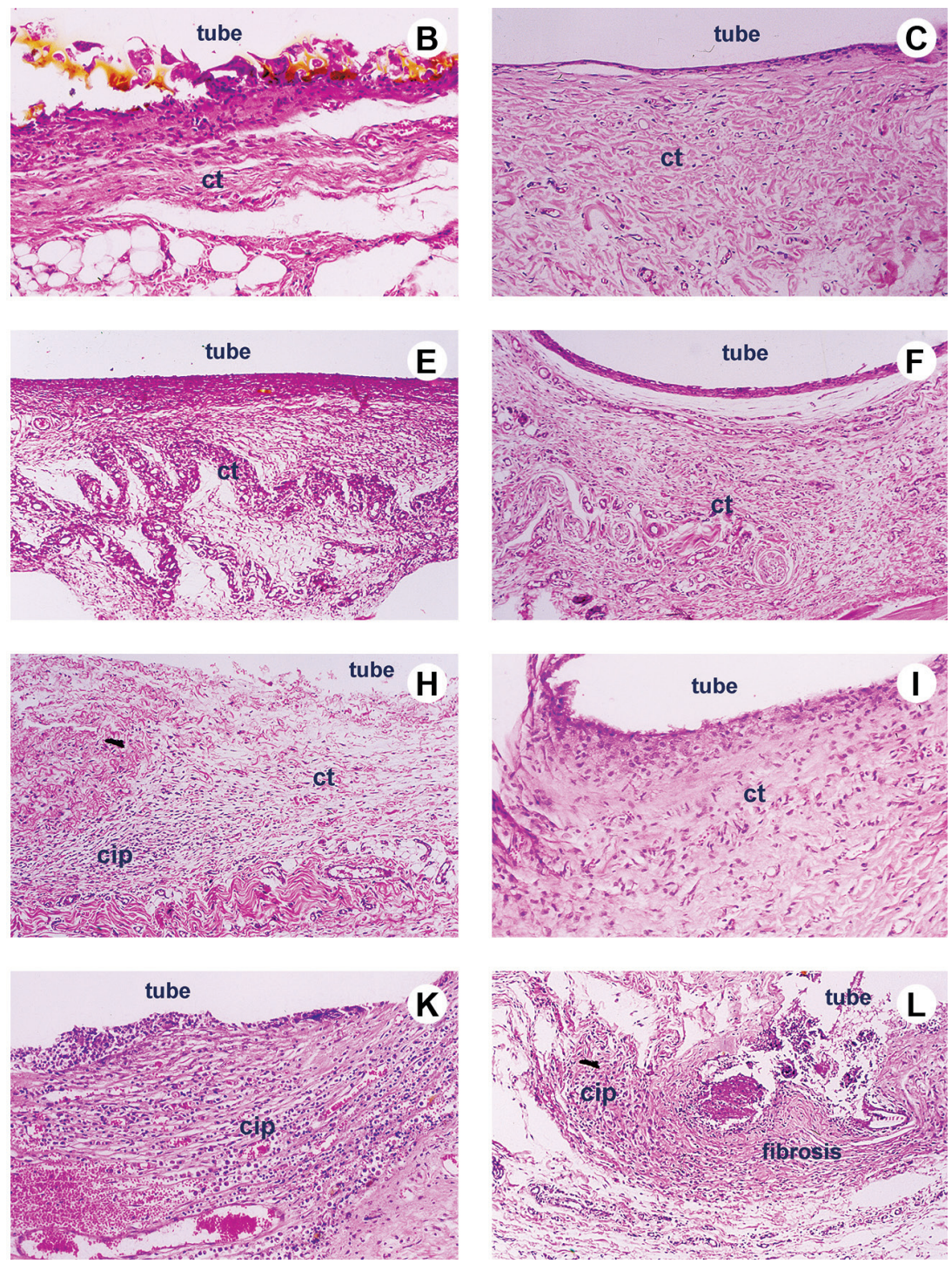

Figure 1. Histological comparison among the groups analyzed. Micrographs A, B and C demonstrate the microscopic features observed in group I (Endofill) on the $7^{\text {th }}, 21^{\text {st }}$ and $45^{\text {th }}$ postoperative days, respectively. Micrograph A shows intense inflammatory reaction induced by the endodontic sealer, while images B and C show a usual connective tissue repair. These facts occurred similarly in group II (AH Plus; micrographs D, E and F) and group III (Acroseal; micrographs G, H and I). In contrast, group IV (Epiphany) shows the presence of an inflammation reaction in all analyzed periods $\left(\mathrm{J}-7^{\text {th }}\right.$ postoperative day; $\mathrm{K}-21^{\text {st }}$ postoperative day and $\mathrm{L}-40^{\text {th }}$ postoperative day). All micrographs were stained with hematoxylin and eosin, at original magnification $\times 100$, except for L (original magnification $\times 40$ ) . cip $=$ chronic inflammation process; acip $=$ acute and chronic inflammation process; ct $=$ usual connective tissue . 
response was observed only on the $7^{\text {th }}$ day post surgery. On the $21^{\text {st }}$ and $45^{\text {th }}$ days postoperative, only fibrous tissue surrounding the polyethylene tubes was observed.

\section{Masson's Trichrome Analysis}

All groups tested positive for fibrous tissue development (Fig. 2). The moda of score distribution in each group can be seen in Table 1. The groups that received tubes filled with Endofill, $\mathrm{AH}$ plus and Acroseal showed well-formed granulation tissue, composed of thin collagen fibers, as soon as the inflammation was finalized. These results were similar to those of the control group, which also presented usual connective tissue on the $7^{\text {th }}$ postoperative day. In addition, fibrosis was observed only peripherally to the polyethylene tubes, especially on the $21^{\text {st }}$ and $45^{\text {th }}$ days post-surgery in groups I, II, III and V. In contrast, specimens filled with Epiphany (Group IV) showed intensive fibrotic tissue deposited on both the $21^{\text {st }}$ and $45^{\text {th }}$ postoperative days, mimicking a pathological fibro-proliferative condition.

\section{$\alpha-S M A^{+}$Cells (Myofibroblasts)}

The positivity to $\alpha$-SMA ${ }^{+}$cells was observed in all groups analyzed on the $7^{\text {th }}$ postoperative day (Fig. $3)$. Only in group V (control) was the myofibroblasts identified as surrounding the polyethylene tube and the mature blood vessels (pericytes), while in groups I to IV, the positivity was present on the cells spread on the inflammatory tissue. On the $21^{\text {st }}$ and $45^{\text {th }}$ day post-surgery, the presence of myofibroblasts in groups I, II and III, decreased significantly, while the usual connective tissue and/or discrete fibrosis surrounding the polyethylene tubes were built. During these periods, the presence of the $\alpha$-SMA was restricted to the blood vessels, characterizing the smooth muscle tissue around the newly formed artery, or surrounding the polyethylene tubes. In contrast, in group IV (Epiphany), the presence of $\alpha-\mathrm{SMA}^{+}$cells remained higher and spread among the
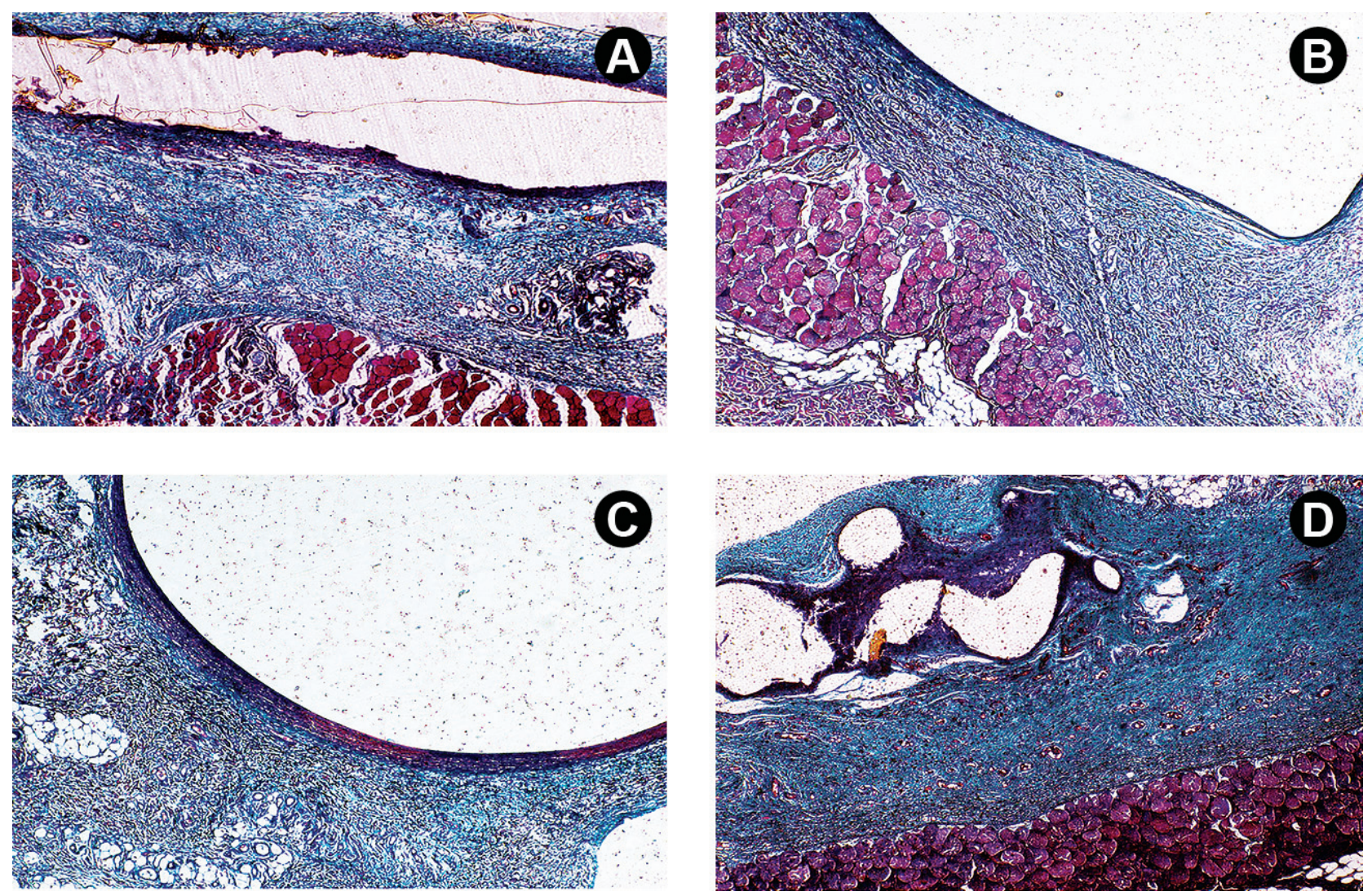

Figure 2. Fibrous deposition on the $40^{\text {th }}$ postoperative day. Micrographs A, B and C reveal thinner and delicate collagen fibers surrounding the polyethylene tube filled by Endofill, AH plus and Acroseal, respectively. Micrograph D exhibits an intense fibrosis peripherally in the tube filled with Epiphany. All micrographs were stained with Masson's Trichrome, at original magnification $\times 200$. 
fibrous tissue in all periods except on the $7^{\text {th }}$ day.

\section{DISCUSSION}

The toxicity of a material is usually evaluated in vitro using methods that allow directing contact between the material and ell cultures. These studies are extremely important because if particular material is considered toxic in vitro it is expected to cause adverse tissue response when used in vivo (12).

According to the manufacturers, all endodontic sealers tested in this study have a satisfactory tissue
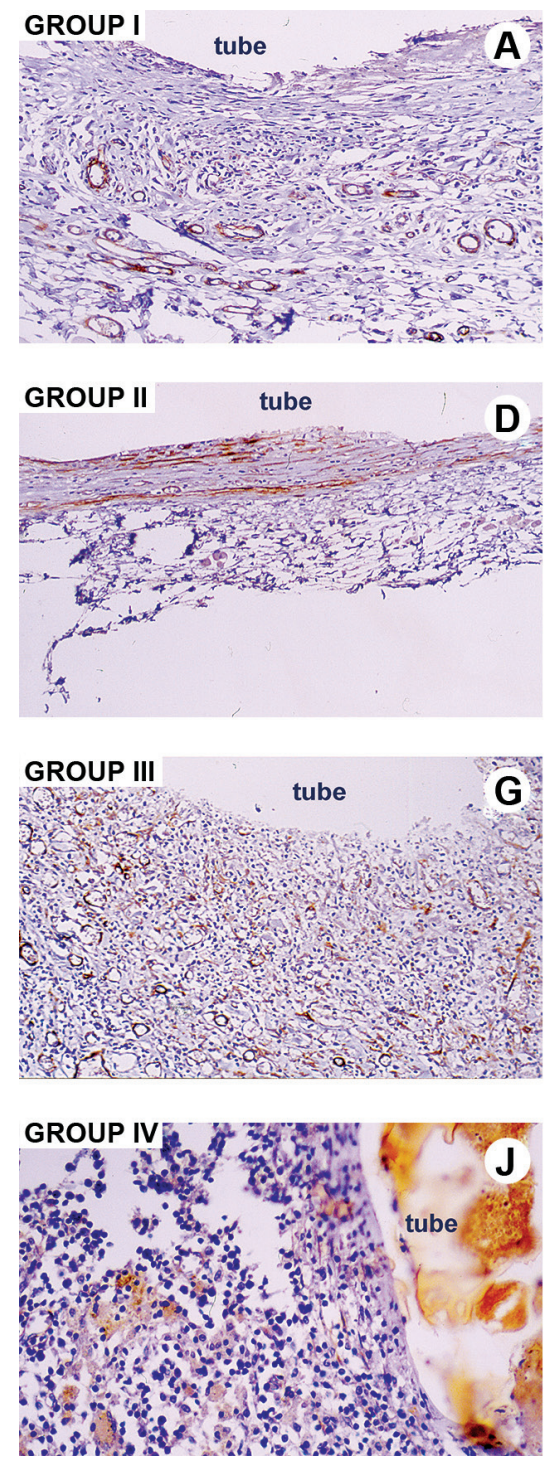
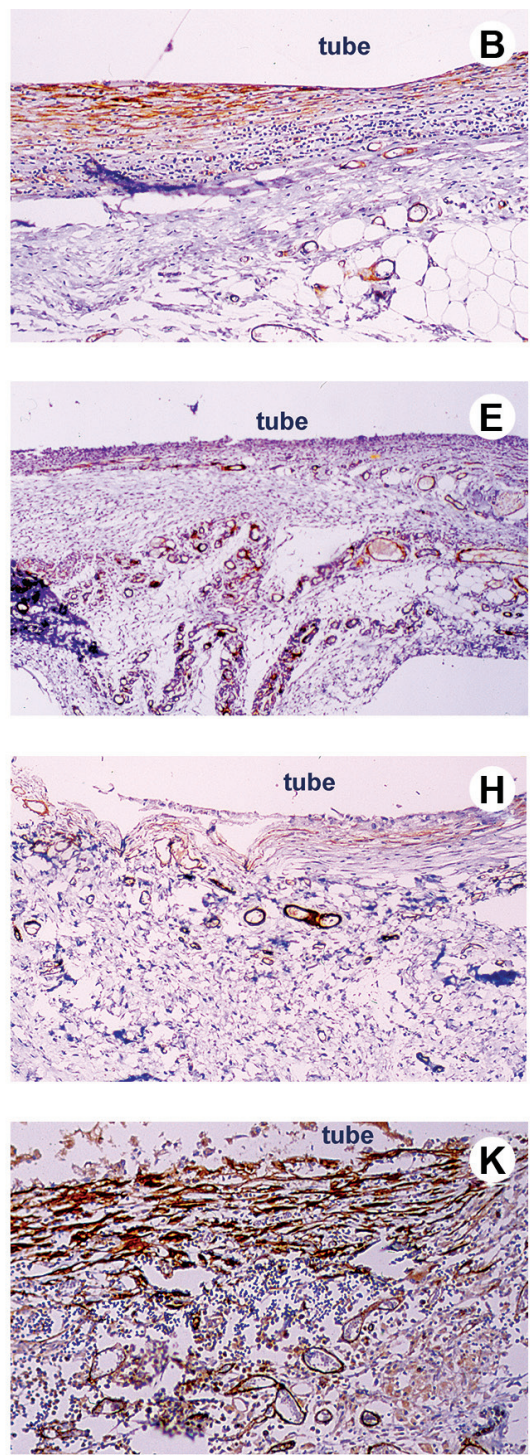
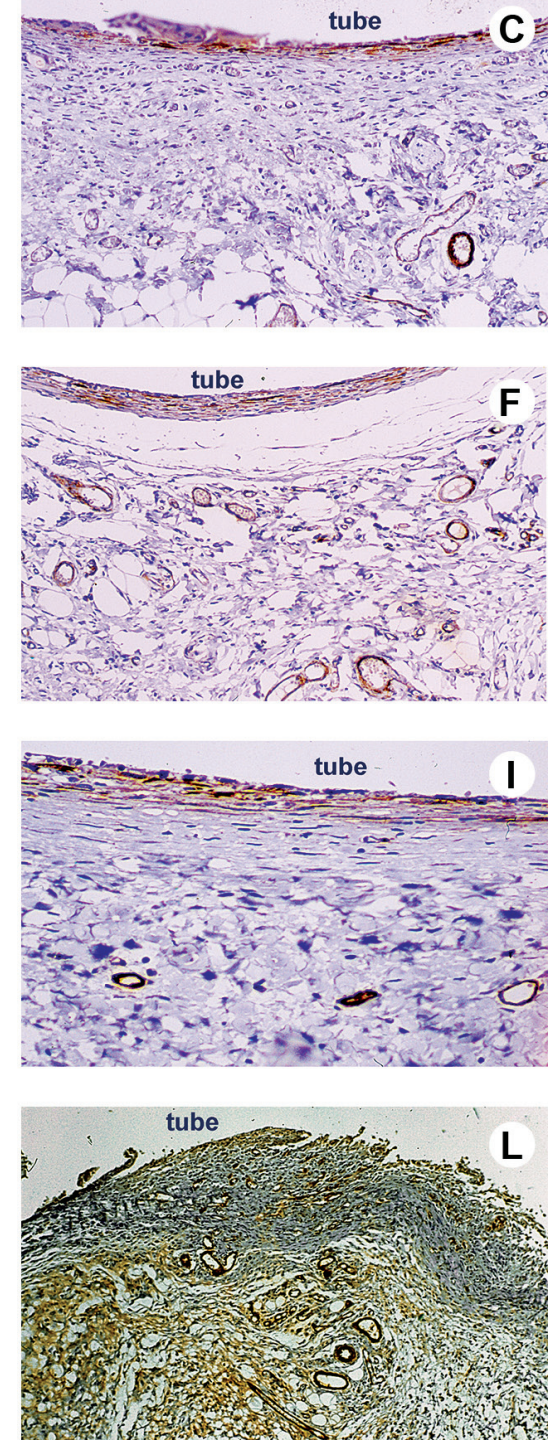

Figure 3. Immunopositivity to $\alpha$-SMA antibody (brownish color) in all groups analyzed. Micrographs A, B and C showed the presence of $\alpha$-SMA ${ }^{+}$cells in group I (Endofill) on $7^{\text {th }}, 21^{\text {st }}$ and $45^{\text {th }}$ postoperative days, respectively. Micrograph A demonstrated the presence of protein surrounding the blood vessels (pericytes) in the granulation tissue, while B and C also revealed the presence of $\alpha-\mathrm{SMA}^{+}$cells (myofibroblast) surrounding the polyethylene tube. Micrographs D, E and F showed, respectively, the presence of discrete quantities of $\alpha$-SMA ${ }^{+}$cells in group II (AH plus) restrict to adjacencies of the polyethylene tube on the $7^{\text {th }}, 21^{\text {st }}$ and $45^{\text {th }}$ days post-operative. Micrograph $\mathrm{G}$ revealed intense $\alpha$-SMA+ cells among the granulation tissue on $7^{\text {th }}$ day post-surgery, while $\mathrm{H}$ and I demonstrate the presence of myofibroblast surrounding the polyethylene tube at $21^{\text {st }}$ and $45^{\text {th }}$ day post-surgery. Figure J showed intense acute inflammatory reaction and scarce $\alpha-\mathrm{SMA}^{+}$cells in the connective tissue around the tube filled with Epiphany (group IV) on $7^{\text {th }}$ day. Micrographs $\mathrm{K}$ and $\mathrm{L}$, respectively for the $21^{\text {st }}$ and $45^{\text {th }}$ postoperative day, revealed higher quantities of $\alpha-\mathrm{SMA}^{+}$cells (myofibroblasts) among the connective tissue (group IV), similar to pathological fibrosis. Original magnification $\times 100$, except for L (original magnification $\times 40$ ). 
response. However, the results of Epiphany in the present study did not corroborate the manufacturer's claims. This sealer induced a persistent inflammatory reaction up to the $45^{\text {th }}$ postoperative day together with a greater presence of myofibroblasts and robust deposition of collagen, mimicking a pathological fibrosis.

Fibrosis is the result of the excess synthesis and deposition of collagen, and it is a characteristic of several connective tissue diseases. It constitutes the final stage in a series of pathological events that begins with altered vascular tonus dysfunction, immunological activation, and extravascular inflammation (13).

The literature states that the ratio between inflammatory reaction and fibrosis has been attributed to persistence and elevation of levels of inflammatory cytokines and growth factors, especially the transforming growth factor beta (TGF- $\beta$ ), an ordinary growth factor produced by platelets and white cells in injured sites (14). Thus, when persistent, these inflammatory cytokines have acted as fibrogenic cytokines, constituting fibrosis since it is responsible for a collagen synthesis contributing to an intensive extracellular matrix deposition (9), and in the same way, inhibition of extracellular matrixdegrading enzymes.

This collagen is usually produced by myofibroblasts, which are terminally differentiated cells that express $\alpha$-SMA filaments and share a hybrid phenotype between fibroblasts and muscle cells (15). The appearance and localization of these cells at sites of wound healing and tissue repair have always been associated with the period of the active fibrous deposition. In fact, they are considered important to the genesis of the extracellular matrix deposition as well as proliferation and differentiation of vascular components among the granulation tissue (16). Furthermore, the literature highlights that the persistence or changes on the life cycle of the myofibroblasts is a hallmark of fibrotic lesions (10). This was also demonstrated by Krieg et al. (13), who analyzed biopsies of fibroproliferative tissue and found a significant increase in the number of myofibroblasts, particularly in the deep derms when compared with usual connective tissue.

In addition, it is noteworthy that the possible ability of myofibroblasts to contribute to fibrosis development may be due to a cause-effect relationship with inflammatory cytokines and growth factors and extracellular matrix deposition (17). In this way, inflammatory cytokines and growth factors, such as TGF- $\beta$, are known for their ability to differentiate mesenchymal cells into myofibroblasts, since they regulate the phenotype by inducing $\alpha$-SMA filament transcription (18). In turn, the contraction of $\alpha$-SMA cells has been strictly correlated with enhanced forcegenerating capacities that may secrete TGF- $\beta$ in an autocrine fashion, which exacerbates the effects of this cytokine, thus contributing to the development of fibrotic conditions (10). This feed-forward loads a mechanism that can help to promote and maintain the myofibroblast differentiation at the same time that the TGF- $\beta$ conduces myofibroblast survival (14), since this relationship suppresses the apoptotic capacity of myofibroblasts (19).

In the present study, the reparative histological frame showed simultaneously inflammatory infiltrate, fibrosis and a remarkable number of myofibroblasts only in tissues that had close contact with Epiphany. The extrapolation of this result may indicate that the presence of myofibroblasts and fibrosis in the group that received Epiphany can be an important component to limit bone matrix deposition during periapical bone repair. This hypothesis is based on the findings of a recent study (20) that demonstrated that myofibroblasts in a bone microenvironment produced a fibrotic frame rich in collagen III, which is a type of collagen that neither surrounds nor supports the adhesion of bone cells.

In contrast, the results present herein also demonstrated that Endofill, AH Plus and Acroseal had a severe toxic effect on the $7^{\text {th }}$ postoperative day, but it decreased significantly on the $21^{\text {st }}$ and $45^{\text {th }}$ postoperative days, which coincided with decrease in the number of myofibroblast and presence of the usual connective tissue that surrounded the polyethylene tubes.

The findings of the present study are in accordance with those of a previous study that found that the severe toxicity of AH Plus and Acroseal in the earlier period may be attributed to formaldehyde release, which decreases significantly after polymerization of the materials and thus attenuates the inflammatory response (21). On the other hand, the toxic effects of Endofill may be due to the eugenol released during sealer contraction (22). In this regard, Hume (23) has stated that in spite of being recognizably aggressive to the tissues eugenol has antiinflammatory properties.

This way, these factors acting together may help explaining the severe initial inflammatory process and subsequent repair usually observed when Endophill, AH Plus and Acroseal were used.

On the basis of the obtained results, it may be 
concluded that the persistence of inflammatory infiltrate induced by an endodontic sealer (Epiphany) may induce the development of fibrosis in combination with the presence of myofibroblasts.

\section{RESUMO}

O objetivo deste estudo foi avaliar a relação entre reação inflamatória induzida por quatro cimentos endodônticos e a presença de fibrose e quantidade de miofibroblastos que apresentam positividade para $\alpha$-SMA. Tubos de polietileno foram preenchidos com o cimento (I: Endofill; II: AH Plus; III: Acroseal; IV: Epiphany) e inseridos em 4 regiões do dorso de 24 ratos Wistar, enquanto 2 tubos vazios (V - controle) foram inseridos em 6 ratos. Após 7, 21 e 45 dias, oito animais foram sacrificados obtendo 6 indivíduos por grupo e 2 para o grupo controle. Os fragmentos foram submetidos ao processamento histológico e à análise imuno-histoquímica para a proteína anti- $\alpha$-SMA. Todos os grupos, exceto o controle, demonstraram notável reação inflamatória no $7^{\circ}$ dia pós-operatório, que também coincidiu com uma grande quantidade de miofibroblastos. No $21^{\circ}$ e $45^{\circ}$ dia pós-operatório, a reação inflamatória induzida pelo Endofill, AH Plus e Acroseal diminuiu significativamente, o que coincidiu com reduzida presença de miofibroblastos e deposição de colágeno normal. Em contraste, no grupo Epiphany, infiltrado inflamatório significativo esteve presente em todos os períodos analisados. A persistência do infiltrado inflamatório induzido por cimento endodôntico pode também provocar uma fibrose associada com a presença de miofibroblastos.

\section{ACKNOWLEDGEMENTS}

The authors would like to thank to Gisele Aihara Haragushiku and Flávia Fagundes Sens Tomazinho for their assistance in the development of this study.

\section{REFERENCES}

1. Silveira CMM, Pinto SCS, Zedebski RAM, Santos FA, Pilatti GL. Biocompatibility of four root canal sealers: a histopathological evaluation in rat subcutaneous connective tissue. Braz Dent J 2011;22:21-27.

2. Garcia LFR, Pires-de-Souza FCP, Teófilo JM, Cestari A, Calefi OS, Ciuffi KJ, et al.. Synthesis and biocompatibility of an experimental glass ionomer cement prepared by a non-hydrolytic sol-gel method. Braz Dent J 2010;21:499-507.

3. Ricucci D. Apical limit of root canal instrumentation and obturation, part 1. Literature review. Int Endod J 1998;31:384-393.

4. Wataha JC. Principles of biocompatibility for dental practitioners. J Prosthet Dent 2001;86:203-209.

5. Silva RAB, Assed S, Nelson-Filho P, Silva LAB, Consolaro A. Subcutaneous tissue response of isogenic mice to calcium hydroxide-based pastes with chlorhexidine. Braz Dent J 2009;20:99-106.

6. Lalis RM, Esaín ML, Kokubu GA, Willis J, Chaves C, Grana DR. Rat subcutaneous tissue response to modified Portland Cement, a new mineral trioxide aggregate. Braz Dent J 2009;20:112-117.
7. Kapoor M, Liu S, Huh K, Parapuram S, Kennedy L, Leask A. Connective tissue growth factor promoter activity in normal and wounded skin. Fibrogenesis Tissue Repair 2008;1:3.

8. Artaza JN, Singh R, Ferrini MG, Braga M, Tsao J, GonzalezCadavid NF. Myostatin promotes a fibrotic phenotypic switch in multipotent $\mathrm{C} 3 \mathrm{H} 10 \mathrm{~T} 1 / 2$ cells without affecting their differentiation into myofibroblasts. J Endocrinol 2008;196:235249.

9. Hinz B, Phan SH, Thannickal VJ, Galli A, Bochaton-Piallat ML, Gabbiani G. The myofibroblast: one function, multiple origins. Am J Pathol 2007;170:1807-1816.

10. Walker GA, Masters KS, Shah DN, Anseth KS, Leinwand LA. Valvular myofibroblast activation by transforming growth factorbeta: implications for pathological extracellular matrix remodeling in heart valve disease. Circ Res 2004;95:253-260.

11. Joseph J, Mohanty M, Mohanan PV. Role of immune cells and inflammatory cytokines in regulation of fibrosis around silicone expander implants. J Mater Sci Mater Med 2011;21:1665-1676.

12. Murray PE, Garcia Godoy C, Garcia Godoy F. How is the biocompatibilty of dental biomaterials evaluated? Med Oral Patol Oral Cir Bucal 2007;12:E258-266.

13. Krieg T, Abraham D, Lafyatis R. Fibrosis in connective tissue disease: the role of the myofibroblast and fibroblast-epithelial cell interactions. Arthritis Res Ther 2007;9 Suppl 2:S4.

14. Wells RG, Discher DE. Matrix elasticity, cytoskeletal tension, and TGF-beta: the insoluble and soluble meet. Sci Signal 2008;1:pe13.

15. Powell DW, Mifflin RC, Valentich JD, Crowe SE, Saada JI, West AB. Myofibroblasts. I. Paracrine cells important in health and disease. Am J Physiol 1999;277:C1-9.

16. Villaschi S, Nicosia RF. Paracrine interactions between fibroblasts and endothelial cells in a serum-free coculture model. Modulation of angiogenesis and collagen gel contraction. Lab Invest 1994;71:291-299.

17. Manetti M, Neumann E, Milia AF, Tarner IH, Bechi P, MatucciCerinic M, et al.. Severe fibrosis and increased expression of fibrogenic cytokines in the gastric wall of systemic sclerosis patients. Arthritis Rheum 2007;56:3442-3447.

18. Brenmoehl J, Miller SN, Hofmann C, Vogl D, Falk W, Scholmerich $\mathrm{J}$, et al.. Transforming growth factor-beta 1 induces intestinal myofibroblast differentiation and modulates their migration. World J Gastroenterol 2009;15:1431-1442.

19. Kissin E, Korn JH. Apoptosis and myofibroblasts in the pathogenesis of systemic sclerosis. Curr Rheumatol Rep 2002;4:129-135.

20. Giovanini AF, Gonzaga CC, Zielak JC, Deliberador TM, Kuczera J, Goringher I, et al.. Platelet-rich plasma (PRP) impairs the craniofacial bone repair associated with its elevated TGF-beta levels and modulates the co-expression between collagen III and alpha-smooth muscle actin. J Orthop Res 2011;29:457-463.

21. Camargo CH, Camargo SE, Valera MC, Hiller KA, Schmalz G, Schweikl H. The induction of cytotoxicity, oxidative stress, and genotoxicity by root canal sealers in mammalian cells. Oral Surg Oral Med Oral Pathol Oral Radiol Endod 2009;108:952-960.

22. Scarparo RK, Grecca FS, Fachin EV. Analysis of tissue reactions to methacrylate resin-based, epoxy resin-based, and zinc oxideeugenol endodontic sealers. J Endod 2009;35:229-232.

23. Hume WR. In vitro studies on the local pharmacodynamics, pharmacology and toxicology of eugenol and zinc oxide-eugenol. Int Endod J 1988;21:130-134.

Received February 24, 2011 Accepted May 29, 2011 